University of St. Thomas, Minnesota

UST Research Online

2009

\title{
Transmission of Shocks from Cross-Listed Markets to the Return and Volatility of Domestic Stocks
}

Ameeta Jaiswal-Dale

University of St. Thomas, Minnesota, a9jaiswal@stthomas.edu

Follow this and additional works at: https://ir.stthomas.edu/ocbfincpub

Part of the Finance and Financial Management Commons

This Article is brought to you for free and open access by the Finance at UST Research Online. It has been accepted for inclusion in Finance Faculty Publications by an authorized administrator of UST Research Online. For more information, please contact asle4660@stthomas.edu. 


\title{
Transmission of Shocks from Cross-Listed Markets to the Return and Volatility of Domestic Stocks
}

\begin{abstract}
This paper examines the transmission of information from German and the U.S. markets to domestic markets using daily price and volume data of 264 stocks from 26 countries that are traded in their home country and cross-listed outside their home market as depository receipts (DRs); in the German market as Global Depository Receipts (GDRs) and in the U.S. as American Depository Receipts (ADRs). We identify days with significant news arrivals in a market through minimum thresholds for both significant absolute price change and trading volume. DR returns and volatilities are affected by the shocks in the markets where they are cross-listed controlling for domestic shocks. Contemporaneous and/or lagged shocks to the cross-listed markets are transmitted to domestic stock returns and volatilities. South American DRs are affected mostly by U.S. shocks, while Eastern European DRs show greater reaction to the German shocks.
\end{abstract}

Keywords: Cross- listing; American Depository Receipts (ADRs); Global Depository Receipts (GDRs); transmission of stocks.

JEL Classification: F37, G14, G15.

The authors wish to acknowledge the helpful comments and suggestions from John Spry. They also wish to express their appreciation to Audry Nogarolle, Lola Odinaeva and Katrina Lawrence for their research assistance. 


\section{Introduction}

There are several strategic reasons for firms to cross-list their stocks in a foreign market (Pagano, Roell, and Zechner, 2002). These strategic motives can be broadly classified into (i) lowering cost of capital (Foerster and Krolyi, 1999; Erunza and Miller, 2000); (ii) improving liquidity (Smith and Sofianos, 1996, Foerster and Karolyi, 1998); and (iii) improving shareholder

protection (Doidge, 2004; Doidge, Karolyi, and Stulz, 2004). It is also observed that firms list in multiple foreign markets. According to Sarkissian and Schill (2004) more than $20 \%$ of the internationally listed stocks are listed in more than one foreign market. The selection of the foreign market to cross-list may depend on firm specific characteristics such as gaining product visibility in the cross-listed market (Saudagaran, 1988); geographic proximity of the cross-listed market to the home country (Sarkissian and Schill, 2004); or the nature of business (Pagano, Roell, and Zechner, 2002).

The most preferred method of cross-listing is to use American Depository Receipts (ADRs). One of the requirements for issuing ADR is that the issuing firm has to follow the U.S. Securities and Exchange Commission's (SEC) guidelines on disclosure. Depending on the level of disclosure and whether the firm is using the ADR to raise new equity, these ADRs are classified into three levels. Level I ADR is the least expensive to issue and has relatively less stringent disclosure requirements, but can only be traded in the over-the-counter (OTC) market in the U.S. and cannot be used to raise new capital. Level II ADRs are allowed to trade in organized exchanges in the U.S., but the issuing foreign firm has to undergo full disclosure requirements as stipulated by SEC and cannot be used to raise new capital. With a Level III ADR, the issuing firm can raise new capital and list the ADR in an organized exchange in U.S., but has to provide to the SEC financial statements prepared according to the U.S. Generally 
Accepted Accounting Principles (GAPP) or submit a detailed summary of the differences in financial reporting between home and the U.S.

A foreign firm that would like to raise capital without meeting the full disclosure requirements can do so by using private placements under Rule 144A of SEC. These private placements have a limited secondary market; only Qualified Institutional Investors (QIBs) are allowed to trade these private placements. One of the other developments in the 144A market is the creation of Global Depositary Receipts (GDRs). Some of the U.S. private placements are issued for global investors and then traded in markets outside the U.S., predominantly in London and several German exchanges. These DRs for sale outside the U.S. are issued under Registration S provision and can be complementary to a 144A issue in the U.S. One of the major differences between ADRs and GDRs is that these GDRs are usually listed in a foreign exchange, but cannot be bought and sold by U.S. citizens. The inherent flexibility of GDRs is one of its most attractive characteristics. However, Reg. S DRs can be combined with either Level 1 (unlisted) or Level II/II (Listed/Listed with IPO), depending upon the issuer's needs.

The motivation for this study is to focus on the trades in the US and on German exchanges while examining the effects of significant systematic shocks in the U.S. and German equity markets on the returns and volatility of stocks that are cross-listed in both markets. The choice of U.S. and Germany as the two cross-listed markets is significant for the following reason: The Henderson, Jegadeesh and Weisbach (2006) study shows that the U.S. is the most frequently used market for raising new equity. Based on the results of their study, during the period between 1990 and 2001, 66.06\% of the total new equity issues by firms outside their home market were in the U.S., while only $2.19 \%$ were in Germany. This difference in new capital raising between the U.S. and Germany is a strong indication that there are significantly 
different reasons for firms to cross-list them in these two markets. Even though it is difficult to identify the specific strategic reasons for choosing the specific market for cross-listing, the difference in raising new capital itself is an indication that firms use the U.S. and German markets for different reasons. Our study contributes to the existing literature in being the first of its kind to look at the effect of systematic shocks in two different cross-listed markets: U.S. and Germany on the return and volatility of the cross-listed stock in its domestic market. This paper develops a methodology that takes into consideration the abnormal trading volume and absolute price changes to first identify significant systematic shocks to a cross-listed market and then uses this information to test whether these shocks are transmitted to the cross-listed firm's domestic returns and volatility.

Cross-listing can change the location of trading activity and price discovery. Baruch, Karolyi, and Lemmon (2007) find that trading volume of a cross-listed stock is likely to migrate to the market where "peer" firms are traded. Several studies using intra-day data indicate that price discovery takes place in the more liquid market ${ }^{1}$. If the price discovery takes place in a market other than the domestic market, then these cross-listed stock returns are more susceptible to the systematic shocks in the market where the price discovery takes place. It is also interesting to study if a stock is listed in multiple markets, systematic shocks in which market has a more significant impact on the cross-listed stock return and volatility. In this study we use a pooled sample of DR returns from 26 different countries to test the effect of systematic shocks in host and domestic market on the returns and return volatilities. Prior research ${ }^{2}$ has indicated that return co-movements can be due to country factors as well as industry factors. Pooling the DR from various industries from a country eliminates most of the industry specific factors and in this

\footnotetext{
${ }^{1}$ Eun and Sabherwal (2003); and Gramming, Melvin, and Schlag (2005) among others.

${ }^{2}$ Heston and Rouwenhorst (1994), Longin and Solnik (1995), Cavaglia, Brightman and Aked (2000). 
respect tests the transmission of shocks at the country level rather than the firm level. This feature is clearly demonstrated in recent research by Bekaert, Hodrick and Zhang (2009), where they found the country factors are more significant in return co-movements as compared to industry factors, whose effects are short-lived.

Information based shocks to a market can be attributed to unanticipated outcomes of scheduled macroeconomic announcements such as unemployment rates, inflation, etc. or totally unanticipated events such as natural or man made calamities, political turmoil and similar events. Many of the previous studies of transmission of shocks across markets have focused exclusively on the effects of scheduled macroeconomic announcements on stock returns and volatility in another market. This paper further contributes to the literature in deviating from the previous studies by using the price and volume data to identify news arrivals in a market. This proxy for news arrival is used to find whether the movement in one market has significant effect on the return and volatility of stocks in another market.

In any given day market participants will be receiving information which they may use in revaluing the stocks. Some of this information will be firm-specific and will have an effect only on the price of that particular stock. Some information may have an effect on a large segment of the market or on the entire market itself. If the investors have heterogeneous beliefs, there may be a large volume of trade between the market participants, but very little change in price. If the market participants have homogeneous beliefs on the information, then there will be considerable increase in volume along with changes in price. If the information is perceived as positive, the volume and price will increase. If it is perceived as negative, then the volume will increase and price will decrease. The model's innovative feature is the use of both volume and 
price change to identify significant shocks and is a general one that can be used in testing the linkages between markets.

In a world were equity markets are subject to several systemic shocks other than those associated with scheduled macroeconomic announcements, it is necessary to use a proxy as developed in this paper to study the transmission of these shocks. In the following literature review we look at some of the prior literature that studied the macroeconomic announcement effects on multiple markets, a strand of literature that looks at the contagion of shocks from one market to another to see if these are caused by economic fundamentals.

The rest of the paper is developed in the following manner. After the literature review in Section 2, the empirical methodology used in this paper is discussed in Section 3. Details of the data are given in Section 4 and the results are discussed in Section 5. Section 6 concludes this paper.

\section{Literature Review}

The effects of macroeconomic announcements in a major market, such as the U.S., are studied in several papers. Booth, Martikainen and Tse (1997), Bracker and Koch (1999), and Martens and Poon (2001) find that macro-economic announcements in the U.S. has an effect on the non-U.S. stock market prices. Bollerslav, Cai and Song (2000) and Graham, Nikkinen and Sahlstrom (2003) demonstrate the varying significance of these announcements from country to country. Using intraday data, Becker, Finnerty, and Friedmann (1995) show that the volatility of the U.K. market increases around regular macroeconomic announcements in the U.S. In a study of six European economies, Nasseh and Strauss (2000) find that stock prices are jointly determined by the macro-economic activity in those countries. One of the draw backs of this 
methodology is that if a macroeconomic announcement confirms to the prior market expectation, there will be very little reaction in the market to that announcement.

The arrival of macroeconomic information alone cannot always explain the extent of the co-movement between national stock markets. King and Wadhwani (1990) develops a theoretical model in which rational agents in one market look at the price changes in another market and try to infer information contents in those price changes. Through this mechanism, a "mistake" in one market can be transmitted into other markets resulting in a contagion. Hamao, Masulis, and $\mathrm{Ng}$ (1990); Lin, Engle and Ito (1994), and Bae and Karolyi (1994) find empirical evidence of contagion between markets. Connolly and Wang (2003) investigate whether economic fundamentals or contagion causes co-movement of international stock markets. Their results indicate that most of the observed return co-movements cannot be attributed to economic fundamentals.

On a firm level cross-listing subjects the price of a stock to react to shocks to its domestic market and the cross-listed markets. Vasconcelos (2005) examines transmission of information while studying the stock price reaction to earning announcements of 338 firms from 40 countries before and after the issue of ADRs, showing that the listing of ADRs affect price behavior in a way consistent with increased investor protection and a reduction in insider trading. Chowdhry and Nanda (1991) explore the rational exploitation of private information of large traders who split their trade across markets. Menkveld et al (2007) and in particular Menkveld (2008) further the work of Chowdhry and Nanda (1991) and test for order splitting by studying trading hours that do not overlap and then extend it by allowing sophisticated investors to time their trades as in Admati and Pfleiderer (1988). 


\section{Methodology}

The methodology developed in this section offers a new approach by using both volume and price changes to identify significant shocks; yet it is well adapted to test the linkages between markets. To elaborate the new approach we begin by identifying days with significant shocks that had a market wide effect on the prices and volume in domestic as well as cross listed markets. A trading day with significantly high trading volume and absolute change in price of the broad market index is an indication that, on that given day an important information event has taken place. Thus the first step in our model is to identify days with significantly high trading volume. A study by Chae (2005) shows that the distribution of daily volume is non-normal, with high skewness and kurtosis and hence ordinary least squared method cannot be used on the level of volume. To alleviate this problem in this study we use a log function of the volume as suggested by Ajinkya and Jain (1989). It is also observed in most markets that the trading volume increases over time and in some cases in a non-linier fashion. As suggested by Chen, Firth, and Rui (2001), using the following regression and correcting for serial correlation, the trend stationarity in trading volumes of different markets is studied.

$$
v_{i t}=\alpha+\beta_{1} T+\beta_{2} T^{2}+\varepsilon_{i t}
$$

Where, $v_{i, t}$ is the log of daily volume for the $i^{\text {th }}$ market at time $t$, T is the trend variable and $\varepsilon_{i, t}$ is the error term in the regression with zero mean and finite variance. By de-trending the volume using the above regression, the error term from the above regression represents deviations in the volume from the trend line.

The second step is to create the proxy variable for days with high volume and absolute change in price. This requires the identification of days when there was a significant change in volume coupled with significant changes in absolute return for the market. The error term from 
equation (1) and the daily price changes are used to create the following dummy variables, as stated in equations (2) and (3). The first dummy variable has a value of 1 , when the error term has a value greater than one standard deviation and the price has increased on that day by more than 0.5 percent. The second dummy variable has a value of 1 when the error term has a value greater than one standard deviation and the index has declined in that day by more than 0.5 percent. These dummy variables capture days in which there is a significant news arrival and significant change in absolute price.

$$
\begin{gathered}
U P_{i, t}=1 \quad \text { if } \varepsilon_{i, t}>\sigma_{\varepsilon_{i}} \text { and } \frac{P_{i, t}-P_{i, t-1}}{P_{i, t-1}}>0.005 \\
=0 \text { otherwise } \\
\begin{aligned}
D N_{i, t}=1 & \text { if } \varepsilon_{i, t}>\sigma_{\varepsilon_{i}} \text { and } \frac{P_{i, t}-P_{i, t-1}}{P_{i, t-1}}<-0.005 \\
= & 0 \text { otherwise }
\end{aligned}
\end{gathered}
$$

Where $\sigma_{\varepsilon_{i}}$ is the standard deviation of the error term, $P_{i, t}$ is the price of the $i^{\text {th }}$ market index at time $t$.

Since many of the DRs are listed in both U.S. and Europe, this paper tests the effects of shocks in domestic, the U.S. and the German markets ${ }^{3}$ on the return of the underlying stock in its domestic market. Most of the domestic markets of the DRs have non-synchronous trading hours with the cross-listed markets. It is possible that a shock in one of the cross-listed markets might happen after the closing of the domestic market and to capture the effect of this shock lagged shock variables are also included in the model.

$$
r_{i t}=\alpha_{1}+\beta_{1} U S_{-} U P_{t}+\beta_{2} U S_{-} U P_{t-1}+\beta_{3} G R_{-} U P_{t}+\beta_{4} G R_{-} U P_{t-1}+\beta_{5} D I \_U P_{t}+\varepsilon_{t}
$$

\footnotetext{
${ }^{3}$ Most of the cross-listings of DRs are either in London and/or one of the German markets, predominantly in Frankfurt and Berlin markets. Historically there is high correlation between the U.S. and U.K. equity markets and hence in this study only the shocks to the German markets are included.
} 
where $r_{i t}$ is the return of the $i^{\text {th }}$ DR at time $t, U S, G R$ and DI are the U.S., German and Domestic indices respectively. In this paper DRs from individual countries are pooled together resulting in 26 separate regressions. If $\beta$ s are significant and positive, then the high volume combined with a positive return in all three markets have an effect on the return of the DR $i$. If only one of the coefficients is significant and positive, then only that market had an effect on the return of the DR. As pointed out by Peterson (2008), in the presence of correlation of residuals across firms, OLS standard errors can be biased. To avoid this problem the Newey-West (Newey and West, 1987) procedure is used in estimating the standard errors.

Similarly, the following regression is used for the entire time period to test the effect of down movement in the U.S. and the German market on the underlying stock returns. $r_{i t}=\alpha_{2}+\beta_{6} U S_{-} D N_{t}+\beta_{7} U S_{-} D N_{t-1}+\beta_{8} G R_{-} D N_{t}+\beta_{9} G R_{-} D N_{t-1}+\beta_{10} D I_{-} D N_{t}+\varepsilon_{t}$

Shocks in cross-listed markets can also have an impact on the volatilities of cross-listed stocks. GARCH volatilities of individual DRs are estimated using the following models:

$$
\begin{gathered}
r_{i, t}=a_{i}+\varepsilon_{i, t} \\
\sigma_{i, t}^{2}=\alpha_{0}+\alpha_{1} \varepsilon_{i, t-1}^{2}+\gamma_{1} \sigma_{i, t-1}^{2}
\end{gathered}
$$

where $r_{i, t}$, is the daily return of the $i^{\text {th }}$ DR at time $t, \varepsilon_{i, t}$ is a random variable of each DR at time $t$ with conditional mean zero and conditional variance. $\sigma_{i, t}^{2}$. After individual volatilities are estimated for each of the cross-listed stocks, the volatilities of DRs from each of the countries are pooled together. A pooled cross-sectional regression analysis is conducted to test the effect of shocks in the U.S. and German markets on the DR's volatility. Since the impact of the news, as captured in the dummy variables, will affect the volatility of the stock the next day, following 
Nikkinen, et al. (2006), the regression equations below are used to test the effect of the U.S. and German markets' upward and downward movements on the volatility of the DRs.

$$
\log \left(\sigma^{2}{ }_{i t+1}\right)-\log \left(\sigma_{i t}^{2}\right)=\alpha_{3}+\beta_{11} U S_{t}+\beta_{12} U S_{t-1}+\beta_{13} G R_{t}+\beta_{14} G R_{t-1}+\beta_{15} D I_{t}+\varepsilon_{t}
$$

In this regression the dummy variables $U S, G R$ and $D I$ are the sum of dummy variables ${ }^{4}$ as estimated in equations (2) and (3) for the U.S., German and domestic markets respectively.

\section{Data}

The data for this study covers the period from September 1995 through August 2005. Daily price and volume information for the 26 country indices and individual DRs for this period was obtained from Bloomberg. The choice of the 26 countries is a function of the number of DRs from each country and the availability of the daily volume data for the representative country index. Only countries with a minimum of DRs listed in both markets are included in this study. Out of the 26 countries in the sample, 14 are from emerging markets and the rest are developed countries. Geographical proximity, flexibility of listing and some possible synchronous trading hours encourage firms to list on specific markets outside their home country. For example, the proximity of the German market encourages several firms from Eastern Europe to list in Germany while continuing to cross list on the U.S. market, whereas, Latin American firms gyrate towards the US market while continuing to list on non-U.S. markets. The list of indices used in this study along with the results from volume regression (1) is given in Table 2. S\&P 500 Index is used as the proxy for the U.S. market and DAX 30 for the German market.

\footnotetext{
${ }^{4}$ Both upward shocks and downward shocks can have an effect on the volatility of the cross-listed stock and hence in this regression the dummy variables capture both upward and downward shocks.
} 


\section{Results}

The summary statistics of returns of the ADRs in their domestic markets are given in Table 1. All domestic returns are calculated in the U.S. dollar terms. The average daily returns are all positive except for Singapore. Emerging markets returns and volatilities are in general greater than those of developed markets. Table 2 summarizes the results of trend stationarity test using equation (1). As expected the results indicate statistically significant linear time trends for most of the countries, except for China, Hungary, Philippines, Poland, Portugal and Turkey. For these countries only the intercept is significant, indicating that there is no significant time trend in the daily trading volume. All indices other than those of these six countries exhibit non-linear growth trend in volume. Adjusted $\mathrm{R}^{2}$ for all countries are statistically significant at $1 \%$ and its range varied from $23.95 \%$ for South Africa to $92.08 \%$ for Finland, indicating that time trends can explain the substantial part of the changes in trading volume in these markets. On a particular day, if there is a significant deviation from the trend line, it is an indication that there was a significant change in volume on that day. Since the model in this paper assumes that under homogenous expectations trading volume increases as a result of information arrivals, only positive deviations from the volume trend are considered as significant.

The fraction of days where there was significant increase in volume and price are given

in Table 3, column two. Since high trading volume days are identified as days where the volume was one standard deviation above the regression line, the maximum number of days with high trading volume should be approximately 0.165 of the total number of days. The actual fraction varies from 0.0733 for South Korea to 0.1497 for India, indicating that the error term from the trend stationarity equation (1) may not be normally distributed. The fifth column in Table 3 indicates the number of high volume without any significant change in prices. This figure varies 
from 0.0194 for Argentina to 0.0504 for Portugal. In general this variable is between 0.02 and 0.04, which indicates that on most of the days with high trading volume there is also significant change in price.

For many of the emerging markets, there are more days with high volume and positive change in price compared to negative change in price. One possible explanation for this is that during the time period covered in this study many of the emerging stock markets experience sustained increase in stock prices. On the other hand, the proportion of positive and negative price movements is more evenly balanced for developed markets. In the last column of Table 3 the average price movement on high volume days is given. Even though in this paper a change of 0.5 percent is considered as significant price change, the averages are uniformly above 1 percent.

The effects of positive and negative shocks in the home and cross-listed markets on ADR returns is tested using a pooled sample of daily returns of ADRs from each of the 26 countries in this study. Equation (4) identifies the contemporaneous relationship between the DR returns and a positive shock in the domestic and foreign markets where the DR is listed. Table 4 gives the results. As expected, the domestic positive shocks has significant positive effect on the DR returns. Controlling for the effects of domestic shocks, for most of the countries in this study, positive shocks in either the U.S. and/or German markets have a positive impact on the returns of the DRs of that country. The only exception is the Indian DRs whose returns are not affected by the positive shocks in the U.S. and German markets.

Results also indicate strong geographic and spatial relationships. Most of the Latin American DRs exhibit strong reaction to the U.S. shocks while the European DRs react more strongly to the positive shocks in the German markets. The only exception to this is the Czech DR returns which did not show any significant reaction to German shocks. Asian DR returns in 
general are affected by shocks in both U.S. and German markets. The significance of lagged shocks indicates the flow of shocks is from the U.S. and German markets to the domestic markets. For example, Australian DR returns react positively to the lagged U.S. and German shocks as well as contemporaneous German shocks. Since the Australian markets close before the U.S. markets open, it will react to the shocks in the U.S. markets only the next day. On the other hand, there is a period of overlap when both Australian and German markets are open and hence the contemporaneous and lagged German shocks have significant impact on the Australian DR returns. This pattern is also observed among the returns of DRs of several other countries, indicating that the flow of information is generally from the cross-listed market to the domestic market.

The effect of negative shocks in the U.S. and German markets on the returns of DRs is tested using equation (5) and the results are given in Table 5. The results are similar to that of the positive shocks, indicating that the DR returns react negatively to shocks in the U.S. and/or German markets. As in the case of positive shocks, the flow of shocks is from the U.S. and German markets to the domestic markets and the geographic and spatial relationships are similar to that of positive shocks. The only anomaly is the DRs from Ukraine, which did not react to the shocks to the cross-listed markets and the domestic market. Since there are only three DRs from Ukraine in the sample, this small sample size may explain this anomalous behavior of Ukrainian DRs. It is also observed that there is asymmetry in the strength of the shocks with negative shocks having a stronger impact on the DR returns than the positive shocks. Negative news usually leads to stronger and more urgent investor over reaction as compared to positive, a possible reason for the asymmetry. Mazouz, Joseph and Joulmer (2009), found similar asymmetry in stock price reaction to positive and negative shocks. 
The relationship between the volatility of the DR returns and the shocks in the U.S. and the German markets are given in Table 6. As expected the domestic shocks had statistically significant impact on the volatility of the DR returns, with the volatility increasing due to either positive or negative shocks. There are observable regional patterns, with the Latin American DR return volatility being affected to a greater degree by the U.S. shocks than the German shocks. On the other hand, the European DR return volatilities are affected more by the German shocks than the U.S. shocks. Spatial separation and the flow of the shocks are again observed in the lagged shocks. Countries in the same time zones exhibit contemporaneous effect of shocks, while those that are in different time zones show that the lagged shocks are the ones that have significant effect on the DR volatility.

Overall the results indicate that there is considerable transmission of shocks from the U.S. and German markets into the returns and volatility of cross-listed stocks. Most of the previous studies that looked into the transmission of shocks due to macro economic announcements did not take into consideration whether the announcement contained any surprise element or not. This may be the reason why these studies were not able to produce significant transmission of shocks due to macro economic announcements.

In this paper the dummy variable for significant information shocks allows us to capture the effects of unanticipated macro economic announcements as well as shocks associated with other random macro events. The use of both U.S. and German stocks in this study allows the effect of two major markets on the return and volatility of cross-listed stocks and the strength of these shocks based on regional affinities. The lagged dummy variables show that the transmission of shocks is from the major markets to the domestic markets. 


\section{Conclusion}

This paper looks at the effect of shocks in foreign markets on the returns and volatilities of domestic stocks that are dual listed in foreign markets. Since DRs are the most common method of cross-listing, this study uses ADRs and GDRs to study the effect of shocks in two prominent markets where these ADRs are listed. This study differs significantly from other studies in the empirical methodology used in identifying the shocks. In previous studies macroeconomic news announcements are used as a proxy for significant news arrivals. But as many studies have indicated, it is the unexpected component of the macroeconomic announcements that will cause the shocks to a market. The model uses the volume and price data to identify the shocks, without specifically identifying the macroeconomic news that caused the significant change in the market returns. The use of this dummy variable also allows us to capture the other random, but significant news events that are not caused by macro economic announcements.

Results of this study clearly indicate that after controlling for the domestic shocks, the DR returns and volatilities are affected by the shocks in the markets where they are cross-listed. The results indicate that the transmission of shocks is from the major markets to the domestic market. Geographic proximity also determines which of the two major markets have greater effect on the domestic stock. South American DRs are affected mostly by U.S. shocks, while the Eastern European DRs show greater reaction to the German shocks. 


\section{References}

Adamati, A. R., Pfleiderer, P., 1988. A theory of intra-day patterns: volume and price volatility. Review of Financial Studies 1, 3-40.

Ajinkya, B. B., Jain, P. C., 1989. The behavior of daily stock market trading volume. Journal of Accounting and Economics 11, 331-359.

Bae, K. H., Karolyi, G. A., 1994. Good news, bad news and international spillovers of stock return volatility between Japan and the U.S. Pacific-Basin Finance Journal 2, 405-438.

Baruch, S., Karolyi, G. A., and Lemmon, M., 2007. Multi-market trading and liquidity: Theory and Evidence. The Journal of Finance 62, 2169-2200

Becker, K.G., Finnerty, J. E., Friedman, J.,1995. Economic news and equity market linkages between the U.S. and U.K. Journal of Banking and Finance 19, 1191-1210.

Bollerslev, T., Caic, J., Song, F. M., 2000. Intraday periodicity, long memory volatility, and macroeconomic announcement effects in the U.S. Treasury bond market. Journal of Empirical Finance 7, 37-55.

Booth, G. G., Martikainen, T., Tsec, Y., 1997. Price and volatility spillovers in Scandinavian stock markets. Journal of Banking and Finance 21, 811-823.

Bracker, K., Koch, P. D., 1999. Economic determinants of the correlation structure across international equity markets. Journal of Economics and Business 51, 443-471.

Cavaglia, S., C. Brightman and M. Aked, 2000. The increasing importance of industry factors, Financial Analyst Journal, 2000, 41-54.

Bekaert, G., Hodrick, R.J., Zhang, X., 2005. International stock return comovements. Journal of Finance, forthcoming. 
Chae, J., 2005. Trading volume, information asymmetry, and timing information. The Journal of Finance 60, 413-442.

Chen, G., Firth, M., Rui, O. M., 2001. The dynamic relation between stock returns, trading volume, and volatility. The Financial Review 38, 153-174.

Chowdhry, B., Nanda, V., 1991. Multimarket trading and market liquidity. Review of Financial Studies 4, 483-511.

Connolly, R. A., Wang, F. A., 2003. International equity market co movements: Economic fundamentals or contagion? Pacific-Basin Finance Journal 11, 23-43.

Doidge, C. (2004) U.S. cross-listings and the private benefits of control: Evidence from dual class firms, Journal of Financial Economics 72, 519-554.

Doidge, C., Karolyi, G. A., and Stulz, R. M. (2004) Why are foreign firms that are listed in the U.S. worth more? Journal of Financial Economics 71, 205-238.

Errunza, V. and D. Miller, 2000, Market segmentation and the cost of capital in international equity markets, Journal of Financial and Quantitative Analysis, 35, 577-600.

Eun, C. and Sabherwal, S. (2003) Cross-border listings and price discovery: Evidence from USlisted Canadian stocks, Journal of Finance 58, 549-574.

Foerster, S. R. and Karolyi, G. A. (1998) Multimarket trading and liquidity: A transaction data analysis of Canada-US interlistings, Journal of International Financial Markets, Institutions and Money 8, 393-412.

Foerster, S. and G.A. Karolyi, 1999, The effects of market segmentation and investor recognition on asset prices: Evidence from foreign stocks listing in the United States, Journal of Finance $54,981-1013$. 
Graham, M., Nikkinen, J., Sahlström, P., 2003. Relative importance of scheduled macroeconomic news for stock market investors. Journal of Economics and Finance 27, $153-165$.

Grammig, J., Melvin, M., and Schlag, C. (2005) Price discovery in international equity trading, Journal of Empirical Finance 12(1) 139-165.

Hamao, Y., Masulis, R. W., Ng, V., 1990. Correlations in price changes and volatility across international stock markets. Review of Financial Studies 3, 281-307.

Henderson, B. J., N. Jegadeesh, and M. S. Weisbach, 2006. World markets for raising new capital. Journal of Financial Economics 82, 63-101.

Heston, S. and K. G. Rouwenhorst, 1994, Does industrial structure explain the benefits of international diversification? Journal of Financial Economics 46, 111-157.

King, M.A., Wadhwani, S., 1990. Transmission of volatility between stock markets, Review of Financial Studies 3, 5-33.

Lin, W., R. F. Engle, Ito, T., 1994. Do bulls and bears move across borders? International transmission of stock returns and volatility, Review of Financial Studies, Vol. 7, No. 3, 507-538. Longin, F. and B. Solnik, 1995, Is the correlation in international equity returns constant: 1960-1990? Journal of International Money and Finance 14, 3-26.

Martens, M., Poon, S., 2001. Returns synchronization and daily correlation dynamics between international stock markets. Journal of Banking and Finance 25, 18051827.

Mazouz, K., Joseph, N.L., and Joulmer, J. Stock price reaction following large one-day price changes: UK evidence, Journal of Banking \& Finance, 33, 1481-93.

Menkveld, A. J., 2008. Splitting orders in overlapping markets: A study of cross-listed 
stocks. Journal of Financial Intermediation 17, 145-174.

Menkveld, A. J., Koopman, S. J., Lucas, A., 2007. Modeling around the clock price discovery for cross listed stocks using state space methods. Journal of Business and Economics Statistics 25, 213-225.

Nasseh, A., Strauss, J., 2000. Stock prices and domestic and international macroeconomic activity: a cointegration approach. The Quarterly Review of Economics and Finance 40, 229245.

Newey, W., West, K., 1987. A simple, positive semi-definite, heteroscedastic and autocorrelation consistent covariance matrix. Econometrica 55, 703-708.

Nikkinen, J., Omran, M., Sahlstrom, P., Aijo, J., 2006. Global stock market reactions to scheduled U.S. macroeconomic news announcements. Global Finance Journal, 17, 92-104. Pagano, M., A.A. Roell, and J. Zechner, 2002, The geography of equity listing: Why do European companies list abroad?, Journal of Finance 57, 2651-2694.

Peterson, M., 2008. Estimating standard errors in finance panel data sets: comparing approaches. Review of Financial Studies, forthcoming.

Sarkissian, S. and Schill, M. (2004) The overseas listing decision: New evidence of proximity preference, Review of Financial Studies 17(3) 769-809.

Smith, K. and Sofianos, G. (1996) The distribution of global trading in NYSE-listed non-U.S. stocks, working paper, NYSE 96-02, New York, NY.

Saudagaran, S. (1988) An empirical study of selected factors influencing the decision to list on foreign stock exchanges, Journal of International Business Studies 19, 101-127. Vasconcelos, H., 2005. Cross-country evidence of the impact of ADRs and institutions on stock price behavior. Working Paper. (Cornerstone Research) 
Table 1

Summary statistics of ADR daily returns

\begin{tabular}{|l|c|c|c|c|c|c|}
\hline Market & $\begin{array}{c}\text { Number } \\
\text { of } \\
\text { ADRs }\end{array}$ & Mean & Std. dev. & Skewness & $\begin{array}{c}\text { Kurtosis } \\
\text { (Excess) }\end{array}$ & $\begin{array}{c}\text { Jarque- } \\
\text { Bera }\end{array}$ \\
\hline Argentina & 11 & 0.001196 & 0.030661 & 1.890988 & 40.92635 & 1356131 \\
\hline Australia & 15 & 0.000462 & 0.029995 & 1.444180 & 20.92026 & 638114 \\
\hline China & 9 & 0.000797 & 0.037031 & 0.818626 & 6.26707 & 27967 \\
\hline $\begin{array}{l}\text { Czech } \\
\text { Republic }\end{array}$ & 4 & 0.002041 & 0.110787 & 3.178785 & 24.1434 & 1352803 \\
\hline Finland & 2 & 0.000720 & 0.028602 & 0.019726 & 6.47931 & 8480 \\
\hline Greece & 7 & 0.000417 & 0.024819 & 0.554867 & 9.11439 & 44586 \\
\hline Hong Kong & 10 & 0.000849 & 0.106498 & 5.781023 & 9.23013 & 964854 \\
\hline Hungary & 6 & 0.000975 & 0.027444 & 0.125026 & 8.14206 & 41428 \\
\hline India & 26 & 0.000832 & 0.033018 & 2.786021 & 27.43435 & 420438 \\
\hline Italy & 2 & 0.000228 & 0.023892 & 0.070049 & 6.17136 & 6038 \\
\hline Japan & 19 & 0.000167 & 0.024930 & 0.387299 & 3.79489 & 26630 \\
\hline South Korea & 17 & 0.014539 & 0.244446 & 8.052828 & 9.48889 & 478520 \\
\hline Mexico & 14 & 0.000786 & 0.030228 & 0.586023 & 5.03568 & 263419 \\
\hline Netherlands & 11 & 0.000507 & 0.027817 & 0.037964 & 7.07052 & 320986 \\
\hline Norway & 5 & 0.000891 & 0.027764 & 0.190999 & 13.7239 & 65383 \\
\hline Philippines & 2 & 0.000493 & 0.048850 & 1.571691 & 17.6006 & 49041 \\
\hline Poland & 11 & 0.000404 & 0.030319 & 0.574943 & 7.84902 & 57976 \\
\hline Portugal & 2 & 0.000176 & 0.018244 & 0.108487 & 2.65154 & 1312 \\
\hline Singapore & 2 & -0.000464 & 0.037606 & 0.905482 & 6.38751 & 5069 \\
\hline South Africa & 13 & 0.000414 & 0.030620 & 0.624129 & 7.97990 & 80236 \\
\hline Spain & 4 & 0.000317 & 0.023307 & 0.232386 & 6.35781 & 13071 \\
\hline Sweden & 4 & 0.000620 & 0.027425 & 0.258665 & 6.73092 & 19022 \\
\hline Switzerland & 11 & 0.000584 & 0.024693 & -0.573320 & 36.49650 & 1279199 \\
\hline Taiwan & 42 & 0.000530 & 0.030463 & 0.151504 & 0.81393 & 2584 \\
\hline Turkey & 12 & 0.001452 & 0.046161 & 1.156740 & 37.38140 & 1489456 \\
\hline Ukraine & 10 & 0.020521 & 0.098416 & 8.875497 & 4.80622 & 848039 \\
\hline & & & & & & \\
\hline
\end{tabular}


Table 2

Tests of trend stationarity in trading volume

In this table the trend stationarity of the trading volume is tested using the following regression:

$$
v_{i t}=\alpha+\beta_{1} t+\beta_{2} t^{2}+\varepsilon_{t i}
$$

Where $v_{t i}$ is the log of trading volume in each market and $t$ is the time trend.

\begin{tabular}{|c|c|c|c|c|}
\hline Market & $\begin{array}{c}\alpha \\
\text { (t-stat) }\end{array}$ & $\begin{array}{c}\beta_{1} \\
\text { (t-stat) }\end{array}$ & $\begin{array}{c}\beta_{2} \\
\text { (t-stat) }\end{array}$ & $\begin{array}{c}R^{2} \\
\text { (F-stat) }\end{array}$ \\
\hline US - S\&P 500 & $\begin{array}{c}18.9331 \\
(426.009)^{*}\end{array}$ & $\begin{array}{c}0.0010 \\
(25.7517)\end{array}$ & $\begin{array}{c}-0.0001 \\
(6.8087)^{*}\end{array}$ & $\begin{array}{c}0.9200 \\
(662.30)\end{array}$ * \\
\hline $\begin{array}{l}\text { Germany - } \\
\text { DAX30 }\end{array}$ & $\begin{array}{c}14.6984 \\
(394.40)^{*}\end{array}$ & $\begin{array}{c}0.0027 \\
(43.8023)\end{array}$ & $\begin{array}{c}-0.0001 \\
(23.0124)\end{array}$ & $\begin{array}{c}0.9306 \\
(785.25)\end{array}$ \\
\hline Argentina & $\begin{array}{c}7.0954 \\
(6.0745)^{*}\end{array}$ & $\begin{array}{c}0.0073 \\
(6.6310)\end{array}$ & $\begin{array}{c}-0.0001 \\
(5.6747)^{*}\end{array}$ & $\begin{array}{c}0.6173 \\
(94.410)\end{array}$ \\
\hline Australia & $\begin{array}{c}18.1211 \\
(707.821)^{*}\end{array}$ & $\begin{array}{c}0.0010 \\
(24.2401)^{*}\end{array}$ & $\begin{array}{c}-0.0001 \\
(6.0034)\end{array}$ & $\begin{array}{c}0.8589 \\
(722.29)\end{array}$ * \\
\hline China & $\begin{array}{c}19.4954 \\
(39.1962)\end{array}$ & $\begin{array}{c}0.0004 \\
(0.6708) \\
\end{array}$ & $\begin{array}{c}0.0000 \\
(0.4120)\end{array}$ & $\begin{array}{c}0.8463 \\
(105.65)\end{array}$ \\
\hline Czech Republic & $\begin{array}{c}13.6633 \\
(23.8781)^{*}\end{array}$ & $c^{0.0010}{ }^{* 7.7291)^{* * *}}$ & $\begin{array}{l}-0.0001 \\
(1.5354)\end{array}$ & $\begin{array}{c}0.2236 \\
(403.14)\end{array}$ \\
\hline Finland & $\begin{array}{c}13.8876 \\
(283.290)\end{array}$ & $\begin{array}{c}0.0025 \\
(30.8125)^{*}\end{array}$ & $\begin{array}{c}-0.0001 \\
(12.6655)^{*}\end{array}$ & $\begin{array}{c}0.9208 \\
(1017.8)\end{array}$ * \\
\hline Greece & $\begin{array}{c}12.6918 \\
(137.724)\end{array}$ & $\begin{array}{c}0.0035 \\
(24.4522)^{*}\end{array}$ & $\begin{array}{c}-0.0001 \\
(17.7271)^{*}\end{array}$ & $\begin{array}{c}0.8435 \\
(624.45)\end{array}$ \\
\hline Hong Kong & $\begin{array}{c}17.8792 \\
(359.196)\end{array}$ & $\begin{array}{c}0.0011 \\
(14.5403)\end{array}$ & $\begin{array}{c}-0.0001 \\
(7.8197)^{*}\end{array}$ & $\begin{array}{c}0.7340 \\
(176.51)^{*}\end{array}$ \\
\hline Hungary & $\begin{array}{c}14.7369 \\
(71.533)^{*}\end{array}$ & $\begin{array}{c}0.0002 \\
(0.6387)\end{array}$ & $\begin{array}{l}-0.0000 \\
(0.6485)\end{array}$ & $\begin{array}{c}0.3097 \\
(310.50)\end{array}$ * \\
\hline India & $\begin{array}{c}2.6785 \\
(0.5062)\end{array}$ & $\begin{array}{c}0.0122 \\
(2.7635)\end{array}$ & $\begin{array}{c}-0.0000 \\
(2.5429)^{* *}\end{array}$ & $\begin{array}{c}0.8195 \\
(115.44)\end{array}$ \\
\hline Italy & $\begin{array}{c}20.9423 \\
(49.662)^{*}\end{array}$ & $\begin{array}{c}-0.0011 \\
(2.7770)^{*}\end{array}$ & $\begin{array}{c}0.0001 \\
(3.6837)\end{array}$ & $\begin{array}{c}0.5196 \\
(240.92)\end{array}$ \\
\hline Japan & $\begin{array}{c}18.8826 \\
(507.133)\end{array}$ & $\begin{array}{c}0.0006 \\
(9.7245)\end{array}$ & $\begin{array}{c}0.0000 \\
(0.5285)\end{array}$ & $\begin{array}{c}0.8301 \\
(539.66)\end{array}$ \\
\hline South Korea & $\begin{array}{c}14.8427 \\
(76.994)\end{array}$ & $\begin{array}{c}0.0033 \\
(10.5809)\end{array}$ & $\begin{array}{c}-0.0001 \\
(5.9161)\end{array}$ & $\begin{array}{c}0.9002 \\
(1477.7)\end{array}$ \\
\hline Mexico & $\begin{array}{c}17.3972 \\
(374.000)\end{array}$ & $\begin{array}{c}0.0004 \\
(6.2639)\end{array}$ & $\begin{array}{c}-0.0001 \\
(3.1174)\end{array}$ & $\begin{array}{c}0.2724 \\
(612.19)\end{array}$ \\
\hline Netherlands & $\begin{array}{c}16.1505 \\
(385.897)^{*}\end{array}$ & $\begin{array}{c}0.0016 \\
(24.2470)^{*}\end{array}$ & $\begin{array}{c}-0.0001 \\
(12.4642)^{*}\end{array}$ & $\begin{array}{c}0.8612 \\
(906.04)^{*}\end{array}$ \\
\hline Norway & $\begin{array}{c}14.1622 \\
(345.258)\end{array}$ & $\begin{array}{c}0.0016 \\
(24.2085)\end{array}$ & $\begin{array}{c}-0.0001 \\
(4.6527)\end{array}$ & $\begin{array}{c}0.8856 \\
(387.14)\end{array}$ \\
\hline
\end{tabular}




\begin{tabular}{|l|c|c|c|c|}
\hline Philippines & $\begin{array}{c}18.5057 \\
(123.884)^{*}\end{array}$ & $\begin{array}{c}-0.0000 \\
(0.1165)\end{array}$ & $\begin{array}{c}-0.0000 \\
(0.4966)\end{array}$ & $\begin{array}{c}0.6148 \\
(401.85)^{*}\end{array}$ \\
\hline Poland & 16.7504 & -0.0015 & 0.0001 & 0.3955 \\
& $(12.523)^{*}$ & $(1.3034)$ & $(1.9157)^{* * *}$ & $(223.70)^{*}$ \\
\hline Portugal & 9.9708 & 0.0001 & 0.0001 & 0.9243 \\
& $(9.5751)^{*}$ & $(0.0467)$ & $(3.3819)^{*}$ & $(374.57)^{*}$ \\
\hline Singapore & 16.6477 & 0.0015 & -0.0001 & 0.8309 \\
& $(205.979)^{*}$ & $(11.402)^{*}$ & $(5.9399)^{*}$ & $(213.85)^{*}$ \\
\hline South Africa & 12.9850 & 0.0043 & -0.0001 & 0.2395 \\
& $(4.2858)^{*}$ & $(1.7010)^{* * *}$ & $(1.5674)$ & $(183.06)^{*}$ \\
\hline Spain & 15.5831 & 0.0023 & -0.0001 & 0.8974 \\
& $(203.045)^{*}$ & $(22.1010)^{*}$ & $(10.5509)$ & $(317.81)^{*}$ \\
\hline Sweden & 15.2761 & 0.0023 & -0.0001 & 0.9391 \\
& $(192.871)^{*}$ & $(17.5348)^{*}$ & $(5.7654)^{*}$ & $(772.23)^{*}$ \\
\hline Switzerland & 13.5062 & 0.0016 & -0.0000 & 0.9429 \\
& $(137.725)^{*}$ & $(10.2588)^{*}$ & $(0.2298)$ & $(827.04)^{*}$ \\
\hline Taiwan & 20.8146 & 0.0007 & -0.0001 & 0.7731 \\
& $(215.264)^{*}$ & $(4.5376)^{*}$ & $(2.1548)^{* *}$ & $(268.30)^{*}$ \\
\hline Turkey & $16.4098 *$ & 0.0021 & -0.0000 & 0.3318 \\
& $(5.9729)^{*}$ & $(0.1589)$ & $(0.1536)$ & $(77.47)^{*}$ \\
\hline Ukraine & 18.6621 & 0.0014 & -0.0001 & 0.9031 \\
& $(332.217)^{*}$ & $(15.8935)^{*}$ & $(5.4297)^{*}$ & $(876.20)^{*}$ \\
\hline
\end{tabular}

* Significance at $1 \%$

** Significance at 5\%

$* * *$ Significance at $10 \%$ 
Table 3

Days with significant increase in volume and prices

In this table the average number of days in which there is significant change in price and volume are given. Significant volume change is defined as one standard deviation above the trend stationary trading volume. The days with high volume and price change are calculated as follows:

$$
\begin{aligned}
U P_{i, t}=1 & \text { if } \varepsilon_{i, t}>\sigma_{\varepsilon_{i}} \text { and } \frac{P_{i, t}-P_{i, t-1}}{P_{i, t-1}}>0.005 \\
& =0 \text { otherwise } \\
D N_{i, t}=1 & \text { if } \varepsilon_{i, t}>\sigma_{\varepsilon_{i}} \text { and } \frac{P_{i, t}-P_{i, t-1}}{P_{i, t-1}}<-0.005 \\
= & 0 \text { otherwise }
\end{aligned}
$$

Where $\varepsilon_{i, t}$ is the error term in the regression in Table 2, $\sigma_{\varepsilon_{i}}$ is the standard deviation of the error term, $P_{i, t}$ is the price of the $i^{\text {th }}$ market index at time $t$.

\begin{tabular}{|l|c|c|c|c|c|}
\hline Market & $\begin{array}{c}\text { Days with } \\
\text { High volume }\end{array}$ & $\boldsymbol{U P}_{\boldsymbol{i}, t}$ & $\boldsymbol{D N}_{\boldsymbol{i}, \boldsymbol{t}}$ & $\begin{array}{c}\text { Days with } \\
\text { High } \\
\text { volume } \\
\text { and no } \\
\text { price } \\
\text { change }\end{array}$ & $\begin{array}{c}\text { Average } \\
\text { absolute } \\
\text { price } \\
\text { change } \\
\text { on High } \\
\text { volume } \\
\text { trading } \\
\text { days }\end{array}$ \\
\hline $\begin{array}{l}\text { U.S. - S\&P } \\
\text { 500 }\end{array}$ & 0.105636 & 0.035461 & 0.030982 & 0.039194 & 0.011678 \\
\hline $\begin{array}{l}\text { Germany - } \\
\text { DAX30 }\end{array}$ & 0.119481 & 0.048980 & 0.041558 & 0.028942 & 0.014840 \\
\hline Argentina & 0.133221 & 0.078415 & 0.035413 & 0.019393 & 0.032674 \\
\hline Australia & 0.117582 & 0.042285 & 0.028561 & 0.046736 & 0.008697 \\
\hline China & 0.134605 & 0.088500 & 0.028087 & 0.018018 & 0.019196 \\
\hline $\begin{array}{l}\text { Czech } \\
\text { Republic }\end{array}$ & 0.116755 & 0.045515 & 0.035620 & 0.035620 & 0.013559 \\
\hline Finland & 0.132485 & 0.054266 & 0.049775 & 0.028443 & 0.023189 \\
\hline Greece & 0.100315 & 0.044453 & 0.025964 & 0.029898 & 0.017484 \\
\hline Hong Kong & 0.140904 & 0.067603 & 0.045955 & 0.027345 & 0.021331 \\
\hline Hungary & 0.140000 & 0.070000 & 0.047500 & 0.022500 & 0.022097 \\
\hline India & 0.149733 & 0.072193 & 0.032086 & 0.045455 & 0.011593 \\
\hline Italy & 0.130132 & 0.046625 & 0.043145 & 0.040362 & 0.012649 \\
\hline Japan & 0.116863 & 0.054054 & 0.030072 & 0.032737 & 0.016227 \\
\hline South Korea & 0.073313 & 0.031808 & 0.024438 & 0.017067 & 0.024293 \\
\hline Mexico & 0.105145 & 0.053318 & 0.033184 & 0.018643 & 0.023562 \\
\hline Netherlands & 0.127997 & 0.048322 & 0.047215 & 0.032460 & 0.013968 \\
\hline Norway & 0.121541 & 0.050486 & 0.031040 & 0.040015 & 0.011442 \\
\hline
\end{tabular}




\begin{tabular}{|l|l|l|l|l|l|}
\hline Philippines & 0.137056 & 0.062866 & 0.038266 & 0.035923 & 0.016766 \\
\hline Poland & 0.118349 & 0.059633 & 0.030275 & 0.028440 & 0.015790 \\
\hline Portugal & 0.131174 & 0.046734 & 0.033988 & 0.050451 & 0.009264 \\
\hline Singapore & 0.144673 & 0.073645 & 0.028411 & 0.042617 & 0.016083 \\
\hline South Africa & 0.130137 & 0.060274 & 0.038356 & 0.031507 & 0.012120 \\
\hline Spain & 0.134917 & 0.050202 & 0.041237 & 0.043478 & 0.012333 \\
\hline Sweden & 0.139117 & 0.056096 & 0.050486 & 0.032536 & 0.017069 \\
\hline Switzerland & 0.137088 & 0.047425 & 0.047682 & 0.042238 & 0.011398 \\
\hline Taiwan & 0.132625 & 0.083038 & 0.025187 & 0.024400 & 0.018421 \\
\hline Turkey & 0.133017 & 0.083135 & 0.028504 & 0.021378 & 0.022552 \\
\hline Ukraine & 0.126949 & 0.040460 & 0.037491 & 0.048998 & 0.009606 \\
\hline
\end{tabular}


Table 4

Contemporaneous relationship between DR returns and positive shocks in the domestic and the U.S. and German markets Regression equation:

$r_{i t}=\alpha_{1}+\beta_{1} U S_{-} U P_{t}+\beta_{2} U S_{-} U P_{t-1}+\beta_{3} G R_{-} U P_{t}+\beta_{4} G R_{-} U P_{t-1}+\beta_{5}$ Domestic Index_UP $+\varepsilon_{t}$

\begin{tabular}{|c|c|c|c|c|c|c|c|}
\hline Country & $a$ & $\beta_{1}$ & $\beta_{2}$ & $\beta_{3}$ & $\beta_{4}$ & $\beta_{5}$ & $\begin{array}{c}\mathrm{R}^{2} \\
\text { (F-stat) }\end{array}$ \\
\hline Argentina & $\begin{array}{c}-0.00089 \\
(2.30937)^{* *}\end{array}$ & $\begin{array}{c}0.00698 \\
(4.03618)^{*}\end{array}$ & $\begin{array}{c}0.00019 \\
(0.11000)\end{array}$ & $\begin{array}{c}0.00514 \\
(2.86272)^{*}\end{array}$ & $\begin{array}{c}0.00687 \\
(3.78511)^{*}\end{array}$ & $\begin{array}{c}0.02216 \\
(17.23286)^{*}\end{array}$ & $\begin{array}{c}0.03709 \\
(69.4745)^{*}\end{array}$ \\
\hline Australia & $\begin{array}{c}-0.00034 \\
(1.98067)^{* *}\end{array}$ & $\begin{array}{l}-0.00028 \\
(0.31552)\end{array}$ & $\begin{array}{c}0.00603 \\
(6.91061)\end{array}$ & $\begin{array}{c}0.00284 \\
(3.75365)\end{array}$ & $\begin{array}{c}0.000057 \\
(0.07518)^{\text {**** }}\end{array}$ & $\begin{array}{c}0.01088 \\
(13.55942)\end{array}$ & $\begin{array}{c}0.00770 \\
(54.3019)^{*}\end{array}$ \\
\hline China & $\begin{array}{l}-0.00031 \\
(0.93394)\end{array}$ & $\begin{array}{c}0.00164 \\
(0.97459)\end{array}$ & $\begin{array}{c}0.00213 \\
(1.30395)\end{array}$ & $\begin{array}{c}0.00304 \\
(1.94527)^{* * *}\end{array}$ & $\begin{array}{c}0.00169 \\
(1.07163)\end{array}$ & $\begin{array}{c}0.00659 \\
(6.11784)^{*}\end{array}$ & $\begin{array}{c}0.00298 \\
(9.1863)^{*}\end{array}$ \\
\hline Czech & $\begin{array}{c}-0.00047 \\
(1.21983) \\
\end{array}$ & $\begin{array}{c}-0.00157 \\
(0.80302) \\
\end{array}$ & $\begin{array}{c}0.00352 \\
(1.86412)^{* * *}\end{array}$ & $\begin{array}{c}0.00230 \\
(1.23915) \\
\end{array}$ & $\begin{array}{c}-0.00252 \\
(1.33622) \\
\end{array}$ & $\begin{array}{c}0.01887 \\
(11.47819)^{*}\end{array}$ & $\begin{array}{c}0.02943 \\
(28.4539)^{*}\end{array}$ \\
\hline Finland & $\begin{array}{c}-0.00156 \\
(3.62121)^{*}\end{array}$ & $\begin{array}{c}0.00179 \\
(0.77570)\end{array}$ & $\begin{array}{c}0.01092 \\
(4.73863)^{*}\end{array}$ & $\begin{array}{c}0.00903 \\
(4.91268)\end{array}$ & $\begin{array}{l}-0.00206 \\
(1.11593)\end{array}$ & $\begin{array}{c}0.02727 \\
(15.42745)\end{array}$ & $\begin{array}{c}0.06471 \\
(68.0791)^{*}\end{array}$ \\
\hline Greece & $\begin{array}{c}-0.00129 \\
(5.40474)\end{array}$ & $\begin{array}{c}0.00089 \\
(0.68871) \\
\end{array}$ & $\begin{array}{c}0.00555 \\
(4.45535)\end{array}$ & $\begin{array}{c}0.00538 \\
(5.12048) \\
\end{array}$ & $\begin{array}{c}0.00329 \\
(3.16528)^{*} \\
\end{array}$ & $\begin{array}{c}0.02384 \\
(22.67871)^{*} \\
\end{array}$ & $\begin{array}{c}0.04537 \\
(118.6534)^{*}\end{array}$ \\
\hline Hong Kong & $\begin{array}{c}-0.00144 \\
(4.94174)\end{array}$ & $\begin{array}{c}0.00007 \\
(0.04984) \\
\end{array}$ & $\begin{array}{c}0.00504 \\
(3.46399)\end{array}$ & $\begin{array}{c}0.00148 \\
(1.18171) \\
\end{array}$ & $\begin{array}{c}0.00347 \\
(2.75009)\end{array}$ & $\begin{array}{c}0.01522 \\
(14.42966)^{*}\end{array}$ & $\begin{array}{c}0.01570 \\
(49.3027)^{*}\end{array}$ \\
\hline Hungary & $\begin{array}{c}-0.00158 \\
(6.16675)^{*}\end{array}$ & $\begin{array}{c}0.00242 \\
(1.79547)^{* * *} \\
\end{array}$ & $\begin{array}{c}0.00859 \\
(6.68193)\end{array}$ & $\begin{array}{c}0.00322 \\
(2.58612)^{*} \\
\end{array}$ & $\begin{array}{c}0.00172 \\
(1.40509 \\
\end{array}$ & $\begin{array}{c}0.02287 \\
(25.14369)^{*}\end{array}$ & $\begin{array}{c}0.05486 \\
(152.1268)^{*}\end{array}$ \\
\hline India & $\begin{array}{c}0.00088 \\
(4.09687)\end{array}$ & $\begin{array}{c}0.00165 \\
(1.29866) \\
\end{array}$ & $\begin{array}{l}-0.00155 \\
(1.25534) \\
\end{array}$ & $\begin{array}{c}0.00036 \\
(0.36622) \\
\end{array}$ & $\begin{array}{c}0.00127 \\
(1.26919) \\
\end{array}$ & $\begin{array}{c}0.01281 \\
(17.13618)\end{array}$ & $\begin{array}{c}0.01608 \\
(61.5244)^{*} \\
\end{array}$ \\
\hline Italy & $\begin{array}{c}-0.00093 \\
(2.08690)^{* *}\end{array}$ & $\begin{array}{c}0.00464 \\
(2.18883)^{* *}\end{array}$ & $\begin{array}{c}0.00376 \\
(1.85042)^{* * *}\end{array}$ & $\begin{array}{c}0.00365 \\
(1.63645)\end{array}$ & $\begin{array}{c}0.00025 \\
(0.11992)\end{array}$ & $\begin{array}{c}0.01372 \\
(5.88522)\end{array}$ & $\begin{array}{c}0.02233 \\
(12.7808)^{*}\end{array}$ \\
\hline Japan & $\begin{array}{c}-0.00147 \\
(11.36986)\end{array}$ & $\begin{array}{c}0.00193 \\
(2.84149)\end{array}$ & $\begin{array}{c}0.00755 \\
(11.50139) \\
\end{array}$ & $\begin{array}{c}0.00130 \\
(2.28961)^{* *} \\
\end{array}$ & $\begin{array}{c}0.00333 \\
(5.85988)\end{array}$ & $\begin{array}{c}0.01984 \\
(38.50368)^{*} \\
\end{array}$ & $\begin{array}{c}0.03882 \\
(345.2090)^{*} \\
\end{array}$ \\
\hline Korea & $\begin{array}{c}-0.00293 \\
(4.06888)\end{array}$ & $\begin{array}{c}0.00675 \\
(1.86118)^{* * *}\end{array}$ & $\begin{array}{c}0.01525 \\
(4.19553)^{*}\end{array}$ & $\begin{array}{c}0.01133 \\
(3.63314)^{*}\end{array}$ & $\begin{array}{l}-0.00233 \\
(0.74126)\end{array}$ & $\begin{array}{c}0.03484 \\
(9.45158)\end{array}$ & $\begin{array}{c}0.00415 \\
(26.0195)^{*}\end{array}$ \\
\hline Mexico & $\begin{array}{c}-0.00137 \\
(6.83459)\end{array}$ & $\begin{array}{c}0.01327 \\
(13.12771)^{*}\end{array}$ & $\begin{array}{c}0.00038 \\
(0.39028)\end{array}$ & $\begin{array}{c}0.00539 \\
(6.10213)\end{array}$ & $\begin{array}{c}0.00093 \\
(1.07706)\end{array}$ & $\begin{array}{c}0.02464 \\
(30.03454)\end{array}$ & $\begin{array}{c}0.04914 \\
(262.2334)^{*}\end{array}$ \\
\hline Netherlands & $\begin{array}{c}-0.00106 \\
(5.78754)^{*}\end{array}$ & $\begin{array}{c}0.00503 \\
(5.31498) *\end{array}$ & $\begin{array}{c}0.00569 \\
(6.16425)^{*}\end{array}$ & $\begin{array}{c}0.00897 \\
(10.86297)^{*}\end{array}$ & $\begin{array}{c}0.00094 \\
(1.18559)\end{array}$ & $\begin{array}{c}0.01500 \\
(18.20568)\end{array}$ & $\begin{array}{c}0.02683 \\
(146.6249)^{*}\end{array}$ \\
\hline Norway & $\begin{array}{c}-0.00049 \\
(1.42815)\end{array}$ & $\begin{array}{c}-0.00246 \\
(1.47608)\end{array}$ & $\begin{array}{c}0.00336 \\
(2.08976)^{* *}\end{array}$ & $\begin{array}{c}0.00680 \\
(4.59800)^{*}\end{array}$ & $\begin{array}{c}0.00566 \\
(3.90541)^{*}\end{array}$ & $\begin{array}{c}0.01507 \\
(10.85404)\end{array}$ & $\begin{array}{c}0.01977 \\
(34.5803)^{*}\end{array}$ \\
\hline
\end{tabular}




\begin{tabular}{|c|c|c|c|c|c|c|c|}
\hline Philippines & $\begin{array}{c}-0.00178 \\
(1.99106)^{* *}\end{array}$ & $\begin{array}{c}0.00090 \\
(0.20750)\end{array}$ & $\begin{array}{c}0.01687 \\
(3.96489)\end{array}$ & $\begin{array}{c}0.00936 \\
(2.38995)^{* *}\end{array}$ & $\begin{array}{l}-0.00160 \\
(0.41559)\end{array}$ & $\begin{array}{c}0.01752 \\
(5.24411)^{*}\end{array}$ & $\begin{array}{c}0.01382 \\
(10.9091)^{*}\end{array}$ \\
\hline Poland & $\begin{array}{c}-0.00139 \\
(5.11324)\end{array}$ & $\begin{array}{c}0.00237 \\
(1.83089)^{* * * *}\end{array}$ & $\begin{array}{c}-0.00154 \\
(1.23923)\end{array}$ & $\begin{array}{c}0.00606 \\
(4.93433)^{*}\end{array}$ & $\begin{array}{l}-0.00056 \\
(0.46406)\end{array}$ & $\begin{array}{c}0.02672 \\
(25.51192)\end{array}$ & $\begin{array}{c}0.05655 \\
(139.4600)^{*}\end{array}$ \\
\hline Portugal & $\begin{array}{c}-0.00137 \\
(4.06398)\end{array}$ & $\begin{array}{c}-0.00040 \\
(0.22919)\end{array}$ & $\begin{array}{c}0.00559 \\
(3.25876)\end{array}$ * & $\begin{array}{c}0.00680 \\
(4.13295)\end{array}$ * & $\begin{array}{c}0.00230 \\
(1.37133)\end{array}$ & $\begin{array}{c}0.01629 \\
(10.77620)\end{array}$ * & $\begin{array}{c}0.03972 \\
(31.1821)^{*}\end{array}$ \\
\hline Singapore & $\begin{array}{c}-0.00365 \\
(4.83582)\end{array}$ & $\begin{array}{c}0.01400 \\
(4.01139)\end{array}$ & $\begin{array}{c}0.00096 \\
(0.27183)\end{array}$ & $\begin{array}{c}0.01160 \\
(3.16687)\end{array}$ & $\begin{array}{c}0.00053 \\
(0.14984)\end{array}$ & $\begin{array}{c}0.03421 \\
(11.63691)^{*}\end{array}$ & $\begin{array}{c}0.06208 \\
(37.5282)^{*}\end{array}$ \\
\hline South Africa & $\begin{array}{c}-0.00006 \\
(0.22157)\end{array}$ & $\begin{array}{c}-0.00017 \\
(0.10294)\end{array}$ & $\begin{array}{c}0.00612 \\
(3.89301)^{*}\end{array}$ & $\begin{array}{c}0.00020 \\
(0.15899)\end{array}$ & $\begin{array}{c}0.00070 \\
(0.54714)\end{array}$ & $\begin{array}{c}0.01408 \\
(12.56342)\end{array}$ & $\begin{array}{c}0.01931 \\
(36.3745)^{*}\end{array}$ \\
\hline Spain & $\begin{array}{c}-0.00082 \\
(2.74026)\end{array}$ & $\begin{array}{c}-0.00063 \\
(0.22768)\end{array}$ & $\begin{array}{c}-0.00383 \\
(1.41877)\end{array}$ & $\begin{array}{c}0.00473 \\
(1.77281)^{* * *}\end{array}$ & $\begin{array}{c}-0.00244 \\
(0.89447)\end{array}$ & $\begin{array}{c}0.02125 \\
(15.93789)\end{array}$ & $\begin{array}{c}0.03610 \\
(52.3201)^{*}\end{array}$ \\
\hline Sweden & $\begin{array}{c}-0.00154 \\
(5.28955)\end{array}$ & $\begin{array}{c}0.00781 \\
(5.06113)\end{array}$ & $\begin{array}{c}0.00673 \\
(4.47227)\end{array}$ & $\begin{array}{c}0.00654 \\
(5.21578)^{*}\end{array}$ & $\begin{array}{c}0.00110 \\
(0.89313)\end{array}$ & $\begin{array}{c}0.02302 \\
(19.56176)\end{array}$ * & $\begin{array}{c}0.05195 \\
(110.7911)^{*}\end{array}$ \\
\hline Switzerland & $\begin{array}{c}-0.00074 \\
(4.24038)\end{array}$ & $\begin{array}{c}0.00320 \\
(3.59488)\end{array}$ & $\begin{array}{c}0.00553 \\
(6.45500)\end{array}$ & $\begin{array}{c}0.00673 \\
(8.51853)\end{array}$ & $\begin{array}{c}0.00043 \\
(0.57526)\end{array}$ & $\begin{array}{c}0.01405 \\
(18.10138)\end{array}$ & $\begin{array}{c}0.02506 \\
(119.3716)^{*}\end{array}$ \\
\hline Taiwan & $\begin{array}{c}-0.00199 \\
(17.10283)\end{array}$ & $\begin{array}{c}-0.00131 \\
(2.26615)^{\text {*** }}\end{array}$ & $\begin{array}{c}0.00465 \\
(8.12443)^{*}\end{array}$ & $\begin{array}{c}0.00105 \\
(2.10869)^{* *}\end{array}$ & $\begin{array}{c}0.00427 \\
(8.62702)\end{array}$ & $\begin{array}{c}0.02481 \\
(66.47012)\end{array}$ & $\begin{array}{c}0.05612 \\
(955.6245)^{*}\end{array}$ \\
\hline Turkey & $\begin{array}{c}-0.00060 \\
(1.38279) \\
\end{array}$ & $\begin{array}{c}0.01995 \\
(5.88369)\end{array}$ & $\begin{array}{c}0.00461 \\
(1.35156)\end{array}$ & $\begin{array}{c}-0.00296 \\
(1.23472) \\
\end{array}$ & $\begin{array}{c}-0.00192 \\
(0.76654) \\
\end{array}$ & $\begin{array}{c}0.02595 \\
(18.05895)\end{array}$ & $\begin{array}{c}0.07230 \\
(76.5277)^{*}\end{array}$ \\
\hline Ukraine & $\begin{array}{l}-0.00050 \\
(0.16406)\end{array}$ & $\begin{array}{c}-0.01179 \\
(0.70036)\end{array}$ & $\begin{array}{c}0.05113 \\
(2.76503)\end{array}$ & $\begin{array}{c}-0.01992 \\
(1.13555) \\
\end{array}$ & $\begin{array}{c}0.05414 \\
(2.95970)\end{array}$ & $\begin{array}{c}0.00149 \\
(0.08139)\end{array}$ & $\begin{array}{c}0.00585 \\
(3.7502)^{*} \\
\end{array}$ \\
\hline
\end{tabular}

* Significance at $1 \%$

** Significance at 5\%

$* * *$ Significance at $10 \%$ 
Table 5

Contemporaneous relationship between DR returns and negative shocks in the domestic and the U.S. and German markets Regression equation:

$r_{i t}=\alpha_{2}+\beta_{6} U S_{-} D N_{t}+\beta_{7} U S_{-} D N_{t-1}+\beta_{8} G R_{-} D N_{t}+\beta_{9} G R_{-} D N_{t-1}+\beta_{10}$ Domestic Index $_{-} D N_{t}+\varepsilon_{t}$

\begin{tabular}{|c|c|c|c|c|c|c|c|}
\hline DN & $a$ & $\beta_{6}$ & $\beta_{7}$ & $\beta_{8}$ & $\beta_{9}$ & $\beta_{10}$ & $\begin{array}{c}\mathrm{R}^{2} \\
\text { (F-stat) }\end{array}$ \\
\hline Argentina & $\begin{array}{c}0.00348 \\
(9.25770)\end{array}$ & $\begin{array}{c}-0.00916 \\
(4.44729)\end{array}$ & $\begin{array}{c}-0.00362 \\
(1.80266)^{* * *}\end{array}$ & $\begin{array}{c}-0.00302 \\
(1.81258)^{* * *}\end{array}$ & $\begin{array}{l}-0.00093 \\
(0.54992) \\
\end{array}$ & $\begin{array}{c}-0.03539 \\
(18.66957)^{*}\end{array}$ & $\begin{array}{c}0.04048 \\
(75.9870)^{*} \\
\end{array}$ \\
\hline Australia & $\begin{array}{c}0.00149 \\
(8.61680)\end{array}$ & $\begin{array}{c}-0.00148 \\
(1.56450) \\
\end{array}$ & $\begin{array}{c}-0.00721 \\
(7.66259)\end{array}$ & $\begin{array}{c}-0.00551 \\
(6.77713)^{*}\end{array}$ & $\begin{array}{c}-0.00303 \\
(3.75623)^{*}\end{array}$ & $\begin{array}{c}-0.01383 \\
(14.42570)\end{array}$ & $\begin{array}{c}0.01045 \\
(73.5447)^{*} \\
\end{array}$ \\
\hline China & $\begin{array}{c}0.00147 \\
(4.44262)\end{array}$ & $\begin{array}{c}0.00107 \\
(0.63251)\end{array}$ & $\begin{array}{l}-0.00215 \\
(1.28049) \\
\end{array}$ & $\begin{array}{c}-0.00771 \\
(4.98798)\end{array}$ & $\begin{array}{c}-0.00492 \\
(3.24103)^{*}\end{array}$ & $\begin{array}{c}-0.01069 \\
(5.73995)\end{array}$ & $\begin{array}{c}0.00483 \\
(14.2799)^{*}\end{array}$ \\
\hline Czech & $\begin{array}{c}-0.00047 \\
(1.21983) \\
\end{array}$ & $\begin{array}{l}-0.00157 \\
(0.80302) \\
\end{array}$ & $\begin{array}{c}0.00352 \\
(1.86412)^{* * *}\end{array}$ & $\begin{array}{c}0.00230 \\
(1.23915) \\
\end{array}$ & $\begin{array}{c}-0.00252 \\
(1.33622) \\
\end{array}$ & $\begin{array}{c}0.01887 \\
(11.47819)^{*}\end{array}$ & $\begin{array}{c}0.02943 \\
(28.4539)^{*} \\
\end{array}$ \\
\hline Finland & $\begin{array}{c}0.00304 \\
(7.16194)\end{array}$ & $\begin{array}{c}-0.00791 \\
(3.36653)\end{array}$ & $\begin{array}{c}-0.01234 \\
(5.35566)\end{array}$ & $\begin{array}{c}-0.00984 \\
(4.92485)^{*} \\
\end{array}$ & $\begin{array}{c}0.00467 \\
(2.39179)^{* *}\end{array}$ & $\begin{array}{c}-0.02876 \\
(15.56520)^{*}\end{array}$ & $\begin{array}{c}0.07460 \\
(79.1537)^{*} \\
\end{array}$ \\
\hline Greece & $\begin{array}{c}0.00185 \\
(7.78727)^{*}\end{array}$ & $\begin{array}{c}-0.00580 \\
(4.63124)\end{array}$ & $\begin{array}{c}-0.00482 \\
(3.85333)^{*} \\
\end{array}$ & $\begin{array}{c}-0.00948 \\
(8.46652)\end{array}$ & $\begin{array}{c}-0.00407 \\
(3.74791)^{*}\end{array}$ & $\begin{array}{c}-0.01934 \\
(13.97646)\end{array}$ & $\begin{array}{c}0.02841 \\
(73.3838)^{*} \\
\end{array}$ \\
\hline Hong Kong & $\begin{array}{c}0.00151 \\
(5.25880)^{*}\end{array}$ & $\begin{array}{c}-0.00166 \\
(1.09770)\end{array}$ & $\begin{array}{c}-0.00801 \\
(5.23771)^{*}\end{array}$ & $\begin{array}{c}-0.00582 \\
(4.44704)\end{array}$ & $\begin{array}{l}-0.00213 \\
(1.63754)\end{array}$ & $\begin{array}{c}-0.01696 \\
(13.59879)\end{array}$ & $\begin{array}{c}0.01749 \\
(54.9132)^{*}\end{array}$ \\
\hline Hungary & $\begin{array}{c}0.00278 \\
(10.98911)^{*}\end{array}$ & $\begin{array}{c}-0.00670 \\
(5.07396)^{*}\end{array}$ & $\begin{array}{c}-0.00703 \\
(5.40539)\end{array}$ & $\begin{array}{c}-0.01338 \\
(11.15846)\end{array}$ & $\begin{array}{c}0.00348 \\
(2.95633)\end{array}$ & $\begin{array}{c}-0.02529 \\
(22.76892)\end{array}$ & $\begin{array}{c}0.06158 \\
(171.8258)^{*}\end{array}$ \\
\hline India & $\begin{array}{c}0.00295 \\
(14.07332)\end{array}$ & $\begin{array}{l}-0.00062 \\
(0.43574)\end{array}$ & $\begin{array}{c}0.00087 \\
(0.62865)\end{array}$ & $\begin{array}{c}-0.00582 \\
(5.50657)^{*}\end{array}$ & $\begin{array}{c}-0.00416 \\
(4.05287)\end{array}$ & $\begin{array}{c}-0.01811 \\
(17.18722)\end{array}$ & $\begin{array}{c}0.01798 \\
(68.8072)^{*}\end{array}$ \\
\hline Italy & $\begin{array}{c}0.00180 \\
(4.10975)\end{array}$ & $\begin{array}{c}-0.00893 \\
(3.98446)^{*}\end{array}$ & $\begin{array}{c}-0.00515 \\
(2.36524)^{* *}\end{array}$ & $\begin{array}{c}-0.00745 \\
(3.64801)^{*}\end{array}$ & $\begin{array}{c}-0.00341 \\
(1.79920)^{* * *}\end{array}$ & $\begin{array}{c}-0.01760 \\
(7.84901)^{*}\end{array}$ & $\begin{array}{c}0.05273 \\
(29.7051)^{*}\end{array}$ \\
\hline Japan & $\begin{array}{c}0.00155 \\
(12.12986)\end{array}$ & $\begin{array}{c}-0.00506 \\
(7.21717)^{*}\end{array}$ & $\begin{array}{c}-0.00802 \\
(11.62718)^{*}\end{array}$ & $\begin{array}{c}-0.00671 \\
(11.01902)^{*}\end{array}$ & $\begin{array}{c}-0.00471 \\
(7.83916)\end{array}$ & $\begin{array}{c}-0.01669 \\
(24.07894)\end{array}$ & $\begin{array}{c}0.02444 \\
(214.5422)^{*}\end{array}$ \\
\hline Korea & $\begin{array}{c}0.00077 \\
(1.08366)\end{array}$ & $\begin{array}{c}-0.00832 \\
(2.17781)^{* * *}\end{array}$ & $\begin{array}{c}-0.00678 \\
(1.78141)^{* * *}\end{array}$ & $\begin{array}{l}-0.00217 \\
(0.65175)\end{array}$ & $\begin{array}{l}-0.00483 \\
(1.48391)\end{array}$ & $\begin{array}{c}-0.02214 \\
(5.25895)^{*}\end{array}$ & $\begin{array}{c}0.00117 \\
(8.0305)^{*}\end{array}$ \\
\hline Mexico & $\begin{array}{c}0.00237 \\
(12.36981)^{*}\end{array}$ & $\begin{array}{c}-0.00778 \\
(7.73274)^{*}\end{array}$ & $\begin{array}{c}-0.00100 \\
(1.00228)^{*}\end{array}$ & $\begin{array}{c}-0.01036 \\
(11.32444)^{*}\end{array}$ & $\begin{array}{l}-0.00037 \\
(0.41127)\end{array}$ & $\begin{array}{c}-0.02562 \\
(25.86246)\end{array}$ & $\begin{array}{c}0.03325 \\
(192.2204)^{*}\end{array}$ \\
\hline Netherlands & $\begin{array}{c}0.00218 \\
(12.10550)\end{array}$ & $\begin{array}{c}-0.00848 \\
(8.68423)^{*}\end{array}$ & $\begin{array}{c}-0.00794 \\
(8.13464)^{*}\end{array}$ & $\begin{array}{c}-0.00928 \\
(10.56706)\end{array}$ & $\begin{array}{c}0.00090 \\
(1.08511)\end{array}$ & $\begin{array}{c}-0.01642 \\
(19.87111)\end{array}$ & $\begin{array}{c}0.03516 \\
(193.5270)^{*}\end{array}$ \\
\hline Norway & $\begin{array}{c}0.00235 \\
(7.27490)\end{array}$ & $\begin{array}{c}-0.00487 \\
(2.80513)\end{array}$ & $\begin{array}{c}-0.00719 \\
(4.22451)^{*}\end{array}$ & $\begin{array}{c}-0.01217 \\
(8.27554)^{*}\end{array}$ & $\begin{array}{l}-0.00101 \\
(0.70489)\end{array}$ & $\begin{array}{c}-0.01563 \\
(8.95989)\end{array}$ & $\begin{array}{c}0.02385 \\
(41.6844)^{*}\end{array}$ \\
\hline
\end{tabular}




\begin{tabular}{|c|c|c|c|c|c|c|c|}
\hline Philippines & $\begin{array}{c}0.00160 \\
(1.80315)^{* * * *}\end{array}$ & $\begin{array}{c}-0.00762 \\
(1.67883)^{* * * *}\end{array}$ & $\begin{array}{c}-0.00877 \\
(1.93617)^{* * *}\end{array}$ & $\begin{array}{c}-0.00834 \\
(2.06458)^{* *}\end{array}$ & $\begin{array}{l}-0.00135 \\
(0.33880)\end{array}$ & $\begin{array}{c}-0.00616 \\
(1.42361)\end{array}$ & $\begin{array}{c}0.00284 \\
(3.0195)^{*}\end{array}$ \\
\hline Poland & $\begin{array}{c}0.00207 \\
(7.68194)^{*}\end{array}$ & $\begin{array}{c}-0.00275 \\
(1.78601)^{* * *}\end{array}$ & $\begin{array}{c}-0.00659 \\
(4.34686)^{*}\end{array}$ & $\begin{array}{c}-0.01343 \\
(11.26740)\end{array}$ & $\begin{array}{c}-0.00249 \\
(2.18043)^{* *}\end{array}$ & $\begin{array}{c}-0.01919 \\
(12.88602)\end{array}$ & $\begin{array}{c}0.03088 \\
(74.6040)^{*}\end{array}$ \\
\hline Portugal & $\begin{array}{c}0.00101 \\
(3.01499)\end{array}$ & $\begin{array}{c}-0.00799 \\
(4.53578)^{*}\end{array}$ & $\begin{array}{l}-0.00242 \\
(1.37653)\end{array}$ & $\begin{array}{c}-0.00838 \\
(5.21585)^{*}\end{array}$ & $\begin{array}{c}0.00081 \\
(0.51358)\end{array}$ & $\begin{array}{c}-0.01344 \\
(7.83940)^{*}\end{array}$ & $\begin{array}{c}0.03400 \\
(26.6826)^{*}\end{array}$ \\
\hline Singapore & $\begin{array}{c}0.00111 \\
(1.44187)\end{array}$ & $\begin{array}{c}-0.01822 \\
(5.02371)\end{array}$ & $\begin{array}{c}-0.00403 \\
(1.10678) \\
\end{array}$ & $\begin{array}{c}-0.00877 \\
(2.55277)^{* *}\end{array}$ & $\begin{array}{l}-0.00172 \\
(0.50726) \\
\end{array}$ & $\begin{array}{c}-0.00734 \\
(1.65329)^{\text {*** }}\end{array}$ & $\begin{array}{c}0.01271 \\
(8.1089)^{*}\end{array}$ \\
\hline South Africa & $\begin{array}{c}0.00202 \\
(7.02233)\end{array}$ & $\begin{array}{c}0.00715 \\
(3.14455)^{*}\end{array}$ & $\begin{array}{l}-0.00278 \\
(1.32124)\end{array}$ & $\begin{array}{c}-0.00617 \\
(4.21045)^{*}\end{array}$ & $\begin{array}{c}-0.00581 \\
(4.00429)\end{array}$ & $\begin{array}{c}-0.01609 \\
(11.24814)^{*}\end{array}$ & $\begin{array}{c}0.01912 \\
(36.0072)^{*}\end{array}$ \\
\hline Spain & $\begin{array}{c}0.00124 \\
(4.15300)^{*}\end{array}$ & $\begin{array}{c}-0.00159 \\
(0.50164)\end{array}$ & $\begin{array}{c}-0.00718 \\
(2.30197)^{* *}\end{array}$ & $\begin{array}{c}0.00201 \\
(0.74754)\end{array}$ & $\begin{array}{c}0.00156 \\
(0.58320)\end{array}$ & $\begin{array}{c}-0.02305 \\
(16.30609)\end{array}$ & $\begin{array}{c}0.03736 \\
(54.1809) *\end{array}$ \\
\hline Sweden & $\begin{array}{c}0.00273 \\
(9.49958)\end{array}$ & $\begin{array}{c}-0.01017 \\
(6.46825)\end{array}$ & $\begin{array}{c}-0.00911 \\
(5.86483)\end{array}$ & $\begin{array}{c}-0.01172 \\
(8.64726)^{*}\end{array}$ & $\begin{array}{c}0.00210 \\
(1.60190)\end{array}$ & $\begin{array}{c}-0.02138 \\
(17.53493)\end{array}$ & $\begin{array}{c}0.05518 \\
(118.0071)^{*}\end{array}$ \\
\hline Switzerland & $\begin{array}{c}0.00190 \\
(11.00167)^{*}\end{array}$ & $\begin{array}{c}-0.00443 \\
(4.75534)^{*}\end{array}$ & $\begin{array}{c}-0.00557 \\
(6.01814)^{*}\end{array}$ & $\begin{array}{c}-0.00810 \\
(9.87161)^{*}\end{array}$ & $\begin{array}{c}0.00076 \\
(0.96778)\end{array}$ & $\begin{array}{c}-0.01354 \\
(17.72718)\end{array}$ & $\begin{array}{c}0.02784 \\
(132.8836)^{*}\end{array}$ \\
\hline Taiwan & $\begin{array}{c}0.00205 \\
(17.94946)\end{array}$ & $\begin{array}{c}-0.00371 \\
(5.84252)\end{array}$ & $\begin{array}{c}-0.01116 \\
(17.84390)^{*}\end{array}$ & $\begin{array}{c}-0.00603 \\
(11.48172)^{*}\end{array}$ & $\begin{array}{c}-0.00506 \\
(9.51343)^{*}\end{array}$ & $\begin{array}{c}-0.02336 \\
(33.48958)\end{array}$ & $\begin{array}{c}0.02271 \\
(374.1936)^{*}\end{array}$ \\
\hline Turkey & $\begin{array}{l}0.00269 \\
(6.0297)\end{array}$ & $\begin{array}{l}0.00473 \\
(1.5669)\end{array}$ & $\begin{array}{l}-0.00482 \\
(-1.6930)\end{array}$ & $\begin{array}{l}-0.00494 \\
(-2.4210)\end{array}$ & $\begin{array}{l}0.00334 \\
(1.6403)\end{array}$ & $\begin{array}{l}-0.02360 \\
(-9.6099)\end{array}$ & $\begin{array}{l}0.020816 \\
(21.5996)\end{array}$ \\
\hline $\begin{array}{c}\text { Ukraine } \\
\text { Check }\end{array}$ & $\begin{array}{c}0.00078 \\
(0.24692) \\
\end{array}$ & $\begin{array}{l}-0.01842 \\
(-1.3574) \\
\end{array}$ & $\begin{array}{l}-0.00143 \\
(-0.1103) \\
\end{array}$ & $\begin{array}{l}0.00970 \\
(0.6533) \\
\end{array}$ & $\begin{array}{l}0.00878 \\
(0.6098) \\
\end{array}$ & $\begin{array}{l}0.03136 \\
(1.5843) \\
\end{array}$ & $\begin{array}{c}-0.000025 \\
(0.9883)\end{array}$ \\
\hline
\end{tabular}

* Significance at $1 \%$

** Significance at 5\%

*** Significance at $10 \%$ 
Table 6

Contemporaneous relationship between stock volatility and shocks in the domestic and the U.S. and German markets

Regression equation:

$\log \left(\sigma^{2}{ }_{i t+1}\right)-\log \left(\sigma_{i t}^{2}\right)=\alpha_{3}+\beta_{11} U S_{t}+\beta_{12} U S_{t-1}+\beta_{13} G R_{t}+\beta_{14} G R_{t-1}+\beta_{15}$ DomesticIndex $_{t}+\varepsilon_{t}$

\begin{tabular}{|c|c|c|c|c|c|c|c|}
\hline Country & $a_{3}$ & $\beta_{11}$ & $\beta_{12}$ & $\beta_{13}$ & $\beta_{14}$ & $\beta_{15}$ & $\begin{array}{c}\mathrm{R}^{2} \\
(\mathrm{~S} \text { of } \mathrm{S})\end{array}$ \\
\hline Argentina & $\begin{array}{c}-0.00818 \\
(2.16795)^{* *}\end{array}$ & $\begin{array}{c}0.03803 \\
(3.33766)^{*}\end{array}$ & $\begin{array}{c}-0.00242 \\
(0.21221)\end{array}$ & $\begin{array}{l}-0.00305 \\
(0.28256)\end{array}$ & $\begin{array}{l}-0.00027 \\
(0.02474)\end{array}$ & $\begin{array}{c}0.08168 \\
(8.63479)^{*}\end{array}$ & $\begin{array}{c}0.00849 \\
(868.469) *\end{array}$ \\
\hline Australia & $\begin{array}{c}-0.00469 \\
(3.23755)^{*}\end{array}$ & $\begin{array}{c}0.00040 \\
(0.07273)^{* * *}\end{array}$ & $\begin{array}{c}0.01861 \\
(3.36175)^{*}\end{array}$ & $\begin{array}{c}0.01682 \\
(3.46072)\end{array}$ & $\begin{array}{l}-0.00063 \\
(0.13057)\end{array}$ & $\begin{array}{c}0.03644 \\
(6.70649)\end{array}$ & $\begin{array}{c}0.02235 \\
(1989.658)^{*}\end{array}$ \\
\hline China & $\begin{array}{c}-0.00632 \\
(2.50103)^{*}\end{array}$ & $\begin{array}{c}0.02063 \\
(2.56367)^{* *} \\
\end{array}$ & $\begin{array}{c}0.02229 \\
(2.78729)^{*}\end{array}$ & $\begin{array}{c}0.01178 \\
(1.56516) \\
\end{array}$ & $\begin{array}{c}-0.00134 \\
(0.17939) \\
\end{array}$ & $\begin{array}{c}0.03618 \\
(5.75637)\end{array}$ & $\begin{array}{c}0.00326 \\
(845.503)^{*}\end{array}$ \\
\hline $\begin{array}{l}\text { Czech } \\
\text { Republic }\end{array}$ & $\begin{array}{c}-0.00871 \\
(1.47919) \\
\end{array}$ & $\begin{array}{c}0.03307 \\
(1.68821)^{\text {*** }}\end{array}$ & $\begin{array}{c}0.00037 \\
(0.01957) \\
\end{array}$ & $\begin{array}{c}0.00799 \\
(0.43128) \\
\end{array}$ & $\begin{array}{c}0.00659 \\
(0.35562) \\
\end{array}$ & $\begin{array}{c}0.08474 \\
(4.84295)\end{array}$ & $\begin{array}{c}0.00900 \\
(261.811)^{*}\end{array}$ \\
\hline Finland & $\begin{array}{c}-0.01493 \\
(5.71555)^{*}\end{array}$ & $\begin{array}{c}0.01433 \\
(1.61193)\end{array}$ & $\begin{array}{c}0.03574 \\
(4.01712)^{*}\end{array}$ & $\begin{array}{c}0.00833 \\
(1.10100)\end{array}$ & $\begin{array}{c}0.00817 \\
(1.07997)\end{array}$ & $\begin{array}{c}0.11075 \\
(15.24078)\end{array}$ & $\begin{array}{c}0.05224 \\
(122.029)^{*}\end{array}$ \\
\hline Greece & $\begin{array}{c}-0.00780 \\
(3.87426)\end{array}$ & $\begin{array}{c}0.00674 \\
(1.02798)\end{array}$ & $\begin{array}{c}0.02418 \\
(3.68023)\end{array}$ & $\begin{array}{c}0.00439 \\
(0.77192)\end{array}$ & $\begin{array}{c}0.00234 \\
(0.41259)\end{array}$ & $\begin{array}{c}0.08986 \\
(13.91475)^{*}\end{array}$ & $\begin{array}{c}0.01786 \\
(539.989) *\end{array}$ \\
\hline Hong Kong & $\begin{array}{c}-0.01093 \\
(4.28658)\end{array}$ & $\begin{array}{c}0.00049 \\
(0.05553)\end{array}$ & $\begin{array}{c}0.04358 \\
(4.89954)\end{array}$ & $\begin{array}{c}0.00901 \\
(1.14845)\end{array}$ & $\begin{array}{l}-0.00235 \\
(0.30057)\end{array}$ & $\begin{array}{c}0.06585 \\
(9.26293)^{*}\end{array}$ & $\begin{array}{c}0.01226 \\
(936.689)^{*}\end{array}$ \\
\hline Hungary & $\begin{array}{c}-0.01634 \\
(5.45665)\end{array}$ & $\begin{array}{c}0.03913 \\
(3.83170)^{*}\end{array}$ & $\begin{array}{c}0.01668 \\
(1.68543)^{* * *}\end{array}$ & $\begin{array}{c}0.05256 \\
(5.59001)^{*}\end{array}$ & $\begin{array}{c}-0.01448 \\
(1.55194)\end{array}$ & $\begin{array}{c}0.12035 \\
(15.62292)\end{array}$ & $\begin{array}{c}0.030017 \\
(784.576) *\end{array}$ \\
\hline India & $\begin{array}{c}0.00012 \\
(0.05737)\end{array}$ & $\begin{array}{c}0.037608265 \\
(4.32033)^{*}\end{array}$ & $\begin{array}{c}0.00901 \\
(1.03529)\end{array}$ & $\begin{array}{c}-0.01225 \\
(1.81466)^{* * *}\end{array}$ & $\begin{array}{c}0.00239 \\
(0.35572)\end{array}$ & $\begin{array}{c}0.03873 \\
(6.74684)^{*}\end{array}$ & $\begin{array}{c}0.004378 \\
(1034.441)^{*}\end{array}$ \\
\hline Ireland & $\begin{array}{c}-0.00551 \\
(1.87976)^{* * *}\end{array}$ & $\begin{array}{c}0.02540 \\
(2.82507)^{*}\end{array}$ & $\begin{array}{c}0.00157 \\
(0.17856) \\
\end{array}$ & $\begin{array}{c}0.00549 \\
(0.64240) \\
\end{array}$ & $\begin{array}{c}0.00836 \\
(0.98584)\end{array}$ & $\begin{array}{c}0.05731 \\
(6.46330)^{*}\end{array}$ & $\begin{array}{c}0.00574 \\
(605.165)^{*}\end{array}$ \\
\hline Italy & $\begin{array}{c}-0.01057 \\
(3.42286)\end{array}$ & $\begin{array}{c}0.03632 \\
(3.61317)^{*}\end{array}$ & $\begin{array}{c}0.00871 \\
(0.89340)\end{array}$ & $\begin{array}{c}0.02589 \\
(2.60797)\end{array}$ & $\begin{array}{c}0.00158 \\
(0.16082)\end{array}$ & $\begin{array}{c}0.06715 \\
(6.31675)^{*}\end{array}$ & $\begin{array}{c}0.03156 \\
(45.939)^{*}\end{array}$ \\
\hline Japan & $\begin{array}{c}-0.00651 \\
(7.89170)^{*}\end{array}$ & $\begin{array}{c}0.00739 \\
(2.72065)^{*}\end{array}$ & $\begin{array}{c}0.00244 \\
(0.89868) \\
\end{array}$ & $\begin{array}{c}0.01274 \\
(5.36687)^{*}\end{array}$ & $\begin{array}{c}0.00596 \\
(2.51120)\end{array}$ & $\begin{array}{c}0.04905 \\
(19.76023)\end{array}$ & $\begin{array}{c}0.01233 \\
(673.340)^{*}\end{array}$ \\
\hline Korea & $\begin{array}{c}-0.00528 \\
(3.05862)^{*}\end{array}$ & $\begin{array}{c}0.02351 \\
(3.40751)^{*}\end{array}$ & $\begin{array}{c}0.01546 \\
(2.24300)^{*}\end{array}$ & $\begin{array}{c}-0.00093 \\
(0.15617)\end{array}$ & $\begin{array}{c}0.00884 \\
(1.47030) \\
\end{array}$ & $\begin{array}{c}0.04848 \\
(6.43698)\end{array}$ & $\begin{array}{c}0.03317 \\
(3334.096)^{*}\end{array}$ \\
\hline Mexico & $\begin{array}{c}-0.01493 \\
(9.26419)^{*}\end{array}$ & $\begin{array}{c}0.03080 \\
(5.47701)^{*}\end{array}$ & $\begin{array}{c}0.01150 \\
(2.04659)^{\text {** }}\end{array}$ & $\begin{array}{c}0.01520 \\
(3.08571)^{*}\end{array}$ & $\begin{array}{c}-0.01112 \\
(2.25667)^{* *}\end{array}$ & $\begin{array}{c}0.11884 \\
(23.46227)\end{array}$ & $\begin{array}{c}0.02167 \\
(1868.167)^{*}\end{array}$ \\
\hline
\end{tabular}




\begin{tabular}{|c|c|c|c|c|c|c|c|}
\hline Netherlands & $\begin{array}{c}-0.00757 \\
(6.28087)^{*}\end{array}$ & $\begin{array}{c}0.02232 \\
(5.17895)\end{array}$ & $\begin{array}{c}0.01448 \\
(3.41260)^{*}\end{array}$ & $\begin{array}{c}0.01907 \\
(4.99502)\end{array}$ & $\begin{array}{c}0.00131 \\
(0.34510) \\
\end{array}$ & $\begin{array}{c}0.04753 \\
(12.82349)\end{array}$ & $\begin{array}{c}0.01290 \\
(783.796)^{*}\end{array}$ \\
\hline Norway & $\begin{array}{c}-0.00786 \\
(3.46340)\end{array}$ & $\begin{array}{c}0.00163 \\
(0.19646) \\
\end{array}$ & $\begin{array}{c}0.01411^{* * *} \\
(1.69081)^{\text {*** }}\end{array}$ & $\begin{array}{c}0.02271 \\
(3.09427)\end{array}$ & $\begin{array}{c}0.00854 \\
(1.16398) \\
\end{array}$ & $\begin{array}{c}0.03834 \\
(4.92620)^{*}\end{array}$ & $\begin{array}{c}0.01298 \\
(400.446)^{*}\end{array}$ \\
\hline Philippines & $\begin{array}{l}-0.00344 \\
(0.46343) \\
\end{array}$ & $\begin{array}{c}0.04356 \\
(1.64752)^{\text {**** }}\end{array}$ & $\begin{array}{c}-0.01327 \\
(0.51026)\end{array}$ & $\begin{array}{c}-0.01835 \\
(0.78719)\end{array}$ & $\begin{array}{c}0.04174 \\
(1.78643)^{* * *}\end{array}$ & $\begin{array}{c}0.08396 \\
(3.81291)\end{array}$ & $\begin{array}{c}0.02355 \\
(629.561)^{*}\end{array}$ \\
\hline Poland & $\begin{array}{c}-0.00778 \\
(3.58425)\end{array}$ & $\begin{array}{c}0.02662 \\
(3.61153)\end{array}$ & $\begin{array}{c}-0.00858 \\
(1.19472) \\
\end{array}$ & $\begin{array}{c}0.01403 \\
(2.18576)^{* *}\end{array}$ & $\begin{array}{c}-0.00653 \\
(1.03791) \\
\end{array}$ & $\begin{array}{c}0.09602 \\
(14.90773)\end{array}$ & $\begin{array}{c}0.02128 \\
(452.035)^{*}\end{array}$ \\
\hline Portugal & $\begin{array}{c}-0.00473 \\
(1.36788) \\
\end{array}$ & $\begin{array}{c}0.00187 \\
(0.15972) \\
\end{array}$ & $\begin{array}{c}0.01286 \\
(1.10375) \\
\end{array}$ & $\begin{array}{c}0.02331 \\
(2.13601)^{* *} \\
\end{array}$ & $\begin{array}{c}0.00682 \\
(0.62222) \\
\end{array}$ & $\begin{array}{c}0.04475 \\
(4.13804)^{*}\end{array}$ & $\begin{array}{c}0.00517 \\
(113.404)^{*}\end{array}$ \\
\hline Singapore & $\begin{array}{c}-0.01707 \\
(3.62520)^{*}\end{array}$ & $\begin{array}{c}0.05920 \\
(3.99634)^{*}\end{array}$ & $\begin{array}{c}0.02974 \\
(2.00540)^{* *}\end{array}$ & $\begin{array}{c}0.00976 \\
(0.68126) \\
\end{array}$ & $\begin{array}{c}0.00543 \\
(0.37942) \\
\end{array}$ & $\begin{array}{c}0.09762 \\
(6.81345)^{*}\end{array}$ & $\begin{array}{c}0.02247 \\
(137.170)^{*}\end{array}$ \\
\hline $\begin{array}{l}\text { South } \\
\text { Africa }\end{array}$ & $\begin{array}{c}-0.00464 \\
(2.04897)^{* *}\end{array}$ & $\begin{array}{c}0.01703 \\
(1.71334)^{\text {*** }} \\
\end{array}$ & $\begin{array}{c}0.01901 \\
(1.97578)^{* *}\end{array}$ & $\begin{array}{c}0.00412 \\
(0.55546) \\
\end{array}$ & $\begin{array}{c}0.01066 \\
(1.44418) \\
\end{array}$ & $\begin{array}{c}0.04143 \\
(6.19797)^{*}\end{array}$ & $\begin{array}{c}0.01153 \\
(330.132)^{*}\end{array}$ \\
\hline Spain & $\begin{array}{c}-0.00659 \\
(2.17729)^{* *}\end{array}$ & $\begin{array}{c}0.00730 \\
(0.37941) \\
\end{array}$ & $\begin{array}{c}0.01437 \\
(0.76599) \\
\end{array}$ & $\begin{array}{l}-0.01745 \\
(0.98903) \\
\end{array}$ & $\begin{array}{c}0.02383 \\
(1.35164) \\
\end{array}$ & $\begin{array}{c}0.07723 \\
(8.51716)\end{array}$ & $\begin{array}{c}0.01033 \\
(329.565)^{*}\end{array}$ \\
\hline Sweden & $\begin{array}{c}-0.00989 \\
(7.01255)^{*}\end{array}$ & $\begin{array}{c}0.01828 \\
(3.85513)\end{array}$ & $\begin{array}{c}0.01615 \\
(3.40190)^{*}\end{array}$ & $\begin{array}{c}0.01381 \\
(3.39119)\end{array}$ & $\begin{array}{c}0.00475 \\
(1.16524)\end{array}$ & $\begin{array}{c}0.05003 \\
(13.04261)^{*}\end{array}$ & $\begin{array}{c}0.02260 \\
(151.467)^{*}\end{array}$ \\
\hline Switzerland & $\begin{array}{c}-0.00984 \\
(7.97800)^{*}\end{array}$ & $\begin{array}{c}0.01711 \\
(4.11599)\end{array}$ & $\begin{array}{c}0.02162 \\
(5.18856)\end{array}$ & $\begin{array}{c}0.02543 \\
(6.75904)\end{array}$ & $\begin{array}{c}0.01134 \\
(3.01287)^{*}\end{array}$ & $\begin{array}{c}0.04349 \\
(11.88679)\end{array}$ & $\begin{array}{c}0.01270 \\
(635.038)^{*}\end{array}$ \\
\hline Taiwan & $\begin{array}{c}-0.00279 \\
(4.11056)\end{array}$ & $\begin{array}{c}0.00754 \\
(3.32039)\end{array}$ & $\begin{array}{c}0.00157 \\
(0.70184) \\
\end{array}$ & $\begin{array}{c}0.00227 \\
(1.17425) \\
\end{array}$ & $\begin{array}{c}0.00604 \\
(3.11412)\end{array}$ & $\begin{array}{c}0.05109 \\
(28.93940)\end{array}$ & $\begin{array}{c}0.01099 \\
(2045.368) *\end{array}$ \\
\hline Turkey & $\begin{array}{c}-0.00965 \\
(2.97001)\end{array}$ & $\begin{array}{c}0.05999 \\
(3.71851)\end{array}$ & $\begin{array}{c}0.02414 \\
(1.50192) \\
\end{array}$ & $\begin{array}{c}0.02526 \\
(2.16833)\end{array}$ * & $\begin{array}{c}0.00431 \\
(0.36344)\end{array}$ & $\begin{array}{c}0.07249 \\
(7.68527)^{*}\end{array}$ & $\begin{array}{c}0.03342 \\
(183.010)^{*}\end{array}$ \\
\hline Ukraine & $\begin{array}{l}-0.01552 \\
(1.06184) \\
\end{array}$ & $\begin{array}{c}0.16232 \\
(2.63903)\end{array}$ & $\begin{array}{c}0.01561 \\
(0.25367) \\
\end{array}$ & $\begin{array}{l}--0.02462 \\
(-0.42049)\end{array}$ & $\begin{array}{c}0.00182 \\
(0.03113) \\
\end{array}$ & $\begin{array}{c}0.09009 \\
(1.47948)\end{array}$ & $\begin{array}{c}0.07154 \\
(3030.002)^{*}\end{array}$ \\
\hline
\end{tabular}

* Significance at $1 \%$

** Significance at 5\%

*** Significance at 10\% 